\title{
GSH Modification as a Marker for Plasma Source and Biological Response Comparison to Plasma Treatment
}

\author{
Pietro Ranieri ${ }^{1, *}$, Hager Mohamed ${ }^{2}$, Brayden Myers ${ }^{1}$, Leah Dobossy ${ }^{2}$, Keely Beyries ${ }^{2}$, \\ Duncan Trosan ${ }^{1}$, Fred C. Krebs ${ }^{2}$, Vandana Miller ${ }^{2,3}$ and Katharina Stapelmann ${ }^{1}$ \\ 1 Department of Nuclear Engineering, North Carolina State University, Raleigh, NC 27605, USA; \\ bgmyers3@ncsu.edu (B.M.); dptrosan@ncsu.edu (D.T.); kstapel@ncsu.edu (K.S.) \\ 2 Department of Microbiology and Immunology, and Institute for Molecular Medicine \& Infectious Disease, \\ Drexel University College of Medicine, Philadelphia, PA 19102, USA; hm469@drexel.edu (H.M.); \\ lmd385@drexel.edu (L.D.); kab625@drexel.edu (K.B.); fck23@drexel.edu (F.C.K.); vam54@drexel.edu (V.M.) \\ 3 Centre for Innovation Competence (ZIK) Plasmatis, Leibniz Institute for Plasma Science and Technology, \\ 17489 Greifswald, Germany \\ * Correspondence: pjranier@ncsu.edu
}

Received: 6 February 2020; Accepted: 9 March 2020; Published: 17 March 2020

\begin{abstract}
This study investigated the use of glutathione as a marker to establish a correlation between plasma parameters and the resultant liquid chemistry from two distinct sources to predefined biological outcomes. Two different plasma sources were operated at parameters that resulted in similar biological responses: cell viability, mitochondrial activity, and the cell surface display of calreticulin. Specific glutathione modifications appeared to be associated with biological responses elicited by plasma. These modifications were more pronounced with increased treatment time for the European Cooperation in Science and Technology Reference Microplasma Jet (COST-Jet) and increased frequency for the dielectric barrier discharge and were correlated with more potent biological responses. No correlations were found when cells or glutathione were exposed to exogenously added long-lived species alone. This implied that short-lived species and other plasma components were required for the induction of cellular responses, as well as glutathione modifications. These results showed that comparisons of medical plasma sources could not rely on measurements of long-lived chemical species; rather, modifications of biomolecules (such as glutathione) might be better predictors of cellular responses to plasma exposure.
\end{abstract}

Keywords: COST-Jet; nspDBD; atmospheric pressure plasmas; low-temperature plasmas; plasma chemistry

\section{Introduction}

Atmospheric pressure plasmas have been shown to exhibit beneficial outcomes for biomedical applications in wound healing [1], cancer [2], and other diseases. These outcomes are attributed to direct or indirect exposure of tissues to plasma-generated reactive oxygen and nitrogen species (RONS) regardless of the application method [3], i.e., directly as in dielectric barrier discharge (DBD) [4], indirectly via atmospheric pressure plasma jet (APPJ) [5], or through plasma-conditioned medium [6]. Investigations correlating the possible biological responses induced by plasma treatment to plasma parameters and components are typically limited to the source used. The configuration, discharge parameters, and environment influence the plasma components that interact with the cells and, thus, the contribution of each component to the cellular response [7-11]. However, direct cause-effect correlations have not yet been defined. Understanding how plasma generated RONS, UV, and electric fields affect cells will allow devices to be tailored for specific biological applications and eventually guide the community toward the determination of the "effective plasma dose" of each device. 
Plasma-generated hydrogen peroxide $\left(\mathrm{H}_{2} \mathrm{O}_{2}\right)$ is theorized to be a major effector of tumor cell killing [12,13]. However, a study comparing the nanosecond pulsed floating-electrode DBD (nspDBD) and the kINPen (an APPJ) showed similar in vitro reductions in the viability of the CT26 colorectal cancer cells at operating parameters where the kINPen produced twice as much $\mathrm{H}_{2} \mathrm{O}_{2}$ as the DBD [14]. These observations indicate that biological responses are not solely induced by long-lived, aqueous $\mathrm{H}_{2} \mathrm{O}_{2}$, and that plasma components other than $\mathrm{H}_{2} \mathrm{O}_{2}$ contribute to cell death [14]. The relative contribution of each component may be different, partly due to the differences in amounts of UV exposure, electric field, and short-lived and charged species in each plasma [4]. Recent literature supports these observations whereby exogenously added RONS are unable to replicate a biological effect observed subsequent to plasma exposure [15]. Therefore, changes in cell viability and other biological responses may not be the result of just RONS but of synergy from all components of plasma discharges where each plasma source produces a unique mix of these effectors. Yet comparisons between devices have traditionally relied on the chemistry produced to explain the observed differences in biological responses [16-18]. This limited chemistry set does not represent the chemical and biochemical processes possible during plasma treatment. For example, UV exposure and applied electric field are individually capable of inducing biological responses and enhance the observed effects of plasma-generated species $[15,19,20]$. In summary, there is a dire need for indicators that accurately reflect the magnitude of the biological response in correlation to all components of plasma treatment.

Recent studies have explored the use of cysteine as such an indicator to trace the short and long-lived species in the liquid phase and their potential biological impacts $[11,21,22]$. The different modifications infer the presence of specific molecules from short-lived species like $\mathrm{OH}$ to end-products like $\mathrm{H}_{2} \mathrm{O}_{2}$. Therefore, modifications to molecules like cysteine, the cysteine-containing glutathione (GSH) [23], or phenol [24] could be reflective of the dominant chemical species from plasma treatment that influence cellular outcomes. The amounts and types of modifications measured could help to optimize plasma treatment regimens, as well as plasma sources for specific applications. This would also provide a potential method for comparison of plasma sources and their potential for biological applications without the need for cell culture. However, the correlation between molecular modifications and specific cellular responses must be established first. To this end, this work showed the comparison between the European Cooperation in Science and Technology Reference Microplasma Jet (COST-Jet) [25] and the nspDBD [26] from both chemical composition and biological response perspective. Further, modifications on the cysteine-containing protein glutathione were compared for an attempt to establish correlations with cellular outcomes.

The plasma discharge components that contribute to biological responses following exposure vary in magnitude between the two devices. The COST-Jet generates myriad RONS in the active plasma, influenced by admixtures and absorbed power, that undergo complex reactions with molecules in the ambient air $[11,25,27,28]$. Short-lived species, such as a nitric oxide (NO), hydroxide radical $(\mathrm{OH})$, and atomic oxygen $(\mathrm{O})$, and long-lived species are transported by gas flow and solvate into the liquid interface $[15,21,29,30]$. While the UV produced in the discharge radiates towards the liquid interface and may influence the treated targets, the electric field does not affect the targets since it is perpendicular to the gas flow (Figure 1). In contrast, the nspDBD produces short and long-lived RONS at the liquid interface. The charged species are driven by the electric field to the liquid interface, whereas the neutral species have diffusion dominated transport and solvate as governed by Henry's law [31]. The UV and electric field components of the nspDBD are directed towards the liquid interface. These nspDBD components individually influence the cellular response at different magnitudes [26]. Therefore, the contribution of any plasma component may significantly influence the cellular response in one treatment approach and be insignificant in another. To compare how these components may affect different plasma treatment approaches, where the components have varying influence on the overall cellular response, the cell's biological outcome must be comparable. 


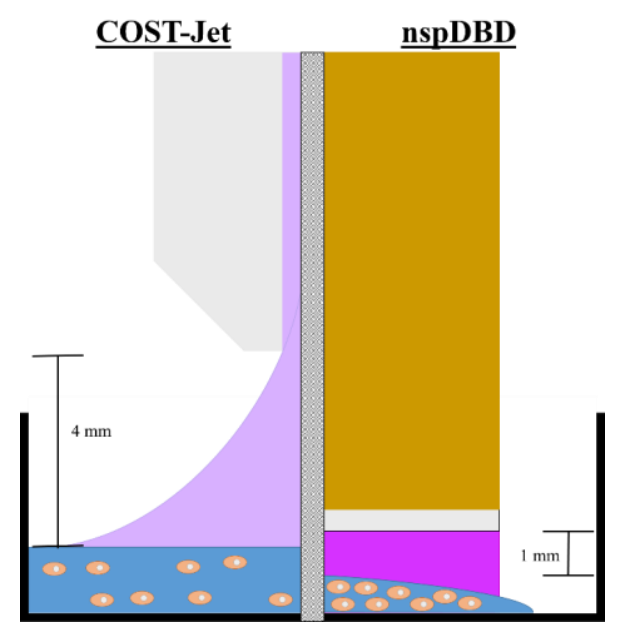

Figure 1. Schematic of plasma treatment setups. The European Cooperation in Science and Technology Reference Microplasma Jet (COST-Jet) was set $4 \mathrm{~mm}$ above $500 \mu \mathrm{L}$ of culture medium or deionized (DI) water. The COST-Jet operated in He with a $0.6 \% \mathrm{O}_{2}$ admixture. The nanosecond pulsed floating-electrode dielectric barrier discharge (nspDBD) was positioned with a $1 \mathrm{~mm}$ gap distance above the liquid surface in ambient air. The treatment volume was $100 \mu \mathrm{L}$.

This study focused on determining if correlations could be established between biological responses of cells to plasma treatment and the modifications to GSH structure caused by plasma. Klinkhammer et al. could show that plasma treatment modified GSH, and the magnitude of these modifications increased with plasma treatment time [23]. We expanded this work by investigating the relationship between observed biological outcomes in Jurkat $\mathrm{T}$ lymphocytes and modifications to GSH from two different plasma sources. First, we demonstrated that these two plasma sources could be operated at parameters where comparable reductions in Jurkat $\mathrm{T}$ lymphocyte viability were achieved. This served as a benchmark for further chemical and biological comparisons of the two plasma sources. Next, we showed that the levels of mitochondrial superoxide $\left(\mathrm{O}_{2}{ }^{-}\right)$production and translocation of calreticulin to the outer surface of the cell membrane (ecto-CRT) were comparable between the two sources at these plasma treatment parameters. The measured concentrations of long-lived RONS were higher in the medium than in deionized water. This indicated that reactions with the medium components produced more RONS in the liquid than without organic compounds. Even with higher concentrations in the medium, the reactions between plasma-generated RONS and the medium components reduced the toxicity observed from $\mathrm{H}_{2} \mathrm{O}_{2}$ alone. We showed that exogenously added long-lived species alone were not responsible for inducing these biological changes. Finally, we evaluated GSH modifications as a potential, scalable marker for correlations between observed biological responses and plasma parameters. Our results showed that changes in a marker, such as GSH, could elucidate the plasma-generated chemistry unique to each source and might correlate with potential biological applications for the plasma source. While the modifications indicated the presence of specific RONS, the biological implications of these RONS were dependent on both their concentration and the cell type.

\section{Materials and Methods}

\subsection{Plasma Setups}

The COST-Jet is a radiofrequency (rf)-driven capacitively coupled plasma jet. The feed gas used in this study was $\mathrm{He}$, with a $0.6 \% \mathrm{O}_{2}$ admixture. The plasma was generated by applying an rf voltage at 13.56 MHz. Helium and oxygen (grade 5) were used for the experiments. The COST-Jet was operated at the ignition voltage to be comparable to reported literature [11]. The plasma treatment parameters are listed in Table 1. 
Table 1. Plasma Treatment Parameters.

\begin{tabular}{ccc}
\hline Parameter & COST-Jet ${ }^{\mathbf{1}}$ & nspDBD $^{\mathbf{2}}$ \\
\hline Treatment Distance & $4 \mathrm{~mm}$ & $1 \mathrm{~mm}$ \\
Treatment Time & $0,1,2,3,4,5 \mathrm{~min}$ & $10 \mathrm{~s}$ \\
Frequency & $13.56 \mathrm{MHz}$ & $30,45,60,75 \mathrm{~Hz}$ \\
Treated Volume & $500 \mu \mathrm{L}$ & $100 \mu \mathrm{L}$ \\
Gas Flow Rate & $\mathrm{He}+0.6 \% \mathrm{O}_{2}(1 \mathrm{slm}+6 \mathrm{sccm})$ & - \\
Pulse Width & - & $20 \mathrm{~ns}$ \\
Rise Time & - & $2 \mathrm{~ns}$ \\
Energy/Pulse & - & $0.9 \mathrm{~mJ} / \mathrm{pulse}$ \\
\hline
\end{tabular}

${ }^{1}$ European Cooperation in Science and Technology Reference Microplasma Jet (COST-Jet), ${ }^{2}$ Nanosecond pulsed dielectric barrier discharge (nspDBD).

The nspDBD used in this work was similar to those described previously [4]. Plasma was generated by applying a high voltage pulse to a copper electrode with a quartz dielectric barrier. As shown in Table 1, the treatment parameters for the nspDBD were fixed at $1 \mathrm{~mm}$ gap distance, $29 \mathrm{kV}$, and exposure duration of $10 \mathrm{~s}$. The frequency of the pulses was varied to change the amount of energy deposited by the discharge.

The viability, MitoSOX, and calreticulin (CRT) experiments and colorimetric assays were performed in 12-well plates, while the Raman samples were prepared in 24-well plates. The treatment schematic for both plasma sources is shown in Figure 1.

\subsection{Cell Culture}

Jurkat cells (clone E6, ATCC ${ }^{\circledR}$ TIB152 ${ }^{\mathrm{TM}}$ ) (American Type Culture Collection, Manassas, VA, USA) were maintained in Roswell Park Memorial Institute (RPMI) 1640 media supplemented with 10\% fetal bovine serum (FBS) (Fisher Scientific, Hampton, NH, USA) and 1\% penicillin/streptomycin $(\mathrm{P} / \mathrm{S})$ (ThermoFisher Scientific, Waltham, MA, USA) in a $37{ }^{\circ} \mathrm{C}$ incubator at $5 \% \mathrm{CO}_{2}$. For COST-Jet experiments, cells were seeded at $3 \times 10^{5}$ cells $/ \mathrm{mL}$ in 12 -well plates with $500 \mu \mathrm{L}$ per well $\left(1.5 \times 10^{5}\right.$ cells/well). Cells exposed to nspDBD plasma were seeded at $1.5 \times 10^{6}$ cells $/ \mathrm{mL}$ with $100 \mu \mathrm{L}$ aliquots initially, then supplemented with $400 \mu \mathrm{L}$ of media immediately after treatment $\left(1.5 \times 10^{5}\right.$ cells/well).

\subsection{Viability Assay}

Jurkat cells were treated by nspDBD plasma at 45 and $75 \mathrm{~Hz}$ for $10 \mathrm{~s}$ or the COST-Jet for 2 and $4 \mathrm{~min}$. Immediately after nspDBD exposure, cells were supplemented with media and then incubated for $24 \mathrm{~h}$ prior to assessing cell viability. To determine percent viable cells, dead cells were stained with $0.5 \mathrm{mg} / \mathrm{mL}$ propidium iodide (ThermoFisher Scientific, Waltham, MA, USA), a cell impermeable dye that enters non-viable cells through damaged membranes and intercalates with the DNA, emitting a fluorescent signal that can be detected using an image cytometer (Nexcelom Bioscience, Vision CBA, Lawrence, MA, USA).

\subsection{MitoSOX Red Assay}

Intracellular mitochondrial $\mathrm{O}_{2}{ }^{-}$production was detected in Jurkat cells $24 \mathrm{~h}$ post-treatment. Cells were washed with PBS and then stained with $5 \mu \mathrm{M}$ MitoSOX ${ }^{\mathrm{TM}}$ Red mitochondrial $\mathrm{O}_{2}{ }^{-}$indicator for 10 min (Molecular Probes, Invitrogen Cat. M36008, Eugene, OR, USA). $\mathrm{O}_{2}{ }^{-}$generation was correlated with fluorescence intensities of measured percent MitoSOX positive cells using the Nexcelom image cytometer.

\subsection{Surface Calreticulin Detection}

Jurkat cells were treated by the nspDBD or the COST-Jet and then incubated for $24 \mathrm{~h}$. Calreticulin on the cell surface was detected by staining cells with calreticulin polyclonal primary antibody (ThermoFisher Scientific, Waltham, MA, USA) and an Alexa Fluor 488 goat anti-rabbit IgG (H + L) 
secondary antibody (ThermoFisher Scientific, Waltham, MA, USA). Percent of calreticulin positive cells in the total cell population and calreticulin fluorescence intensity were measured using the Nexcelom image cytometer. Analyses of fluorescence intensity were done on FCS Express version 4 (De Novo ${ }^{\mathrm{TM}}$ software, Pasadena, CA, USA, 2011).

\subsection{Colorimetric Assays for Chemical Analysis}

Plasma treated samples were analyzed immediately for $\mathrm{H}_{2} \mathrm{O}_{2}$ and nitrite $\left(\mathrm{NO}_{2}{ }^{-}\right)$concentrations using colorimetric assays. The phenanthroline derivative-copper method (Millipore Sigma, USA, Burlington, MA, USA) and Griess reagent (Molecular Probes, Invitrogen Cat. G7921, Eugene, OR, USA) were used for $\mathrm{H}_{2} \mathrm{O}_{2}$ and $\mathrm{NO}_{2}{ }^{-}$measurements, respectively. For $\mathrm{H}_{2} \mathrm{O}_{2}$ detection, $150 \mu \mathrm{L}$ of plasma-treated liquid (deionized (DI) water or RPMI supplemented with $10 \% \mathrm{FBS}$ and $1 \% \mathrm{P} / \mathrm{S}$ ) was mixed with $15 \mu \mathrm{L}$ each of the kit reagents: $\mathrm{H}_{2} \mathrm{O}_{2}-1$ and $\mathrm{H}_{2} \mathrm{O}_{2}-2$. The sample was incubated at room temperature in the dark for $10 \mathrm{~min}$ prior to measuring the absorption at $450 \mathrm{~nm}$. For $\mathrm{NO}_{2}{ }^{-}, 150 \mu \mathrm{L}$ of plasma-treated liquid was mixed with $130 \mu \mathrm{L}$ of deionized water and $20 \mu \mathrm{L}$ of the Griess reagent. The sample was incubated at room temperature in the dark for $30 \mathrm{~min}$. The absorption was measured at $548 \mathrm{~nm}$. All absorption measurements were taken on a plate reader (Fluoroskan Ascent ${ }^{\mathrm{TM}} \mathrm{FL}$, Thermofisher Scientific, Waltham, MA, USA) in flat-bottomed 96-well plates.

\subsection{Raman Spectroscopy of Glutathione Modifications}

Glutathione (GSH) (Thermofisher Scientific, Waltham, MA, USA) samples were prepared in deionized water at $10 \mathrm{mg} / \mathrm{mL}$. For the nspDBD-treated samples, $10 \mu \mathrm{L}$ was treated at 45 and $75 \mathrm{~Hz}$, frozen at $-80^{\circ} \mathrm{C}$ and shipped to North Carolina State University for analysis. Upon arrival, $10 \mu \mathrm{L}$ of the sample was dried on a calcium fluoride window overnight using a desiccator. For the COST-Jet, $500 \mu \mathrm{L}$ samples were treated for 2 and $4 \mathrm{~min}$ at North Carolina State University. The $10 \mu \mathrm{L}$ aliquots were dried overnight on the calcium fluoride window, similar to the nspDBD-treated samples. Measurements were performed on a confocal Raman microscope (Senterra II, Bruker Corporation, Billerica, MA, USA) with a wavelength of $532 \mathrm{~nm}$ at $20 \mathrm{~mW}$. All measurements were taken using a 50× objective lens (OLYMPUS BX53M, Olympus, Waltham, MA). The spectra were measured from $0-3700 \mathrm{~cm}^{-1}$ using the OPUS software (Bruker Optic GmbH, Version 7.8, Ettlingen, Germany). For each sample, 10 spectra were averaged for 10 different positions with an integration time of $1 \mathrm{~s}$, similar to previous studies [23]. Background measurements were performed prior to sample measurement with the laser aperture fully closed. The raw sample spectra were analyzed by performing a rubberband baseline correction using the OPUS software, as described in [32]. Briefly, the spectrum is divided into segments, and the lowest point in each segment is used to estimate the baseline. For this study, 100 segments were used to define the baseline. After the baseline subtraction, spectra were normalized to the integrated $\mathrm{C}-\mathrm{H}$ stretching peak at $2950 \mathrm{~cm}^{-1}$. All measurements were done in triplicate.

\subsection{Statistical Analysis}

Each experiment was performed in triplicate unless otherwise stated. The data were plotted as mean and standard deviation. Graphs were plotted in Origin 2018b (OriginLab Corporation, Northampton, MA, USA).

\section{Results}

\subsection{Comparison of Cellular Responses between COST-Jet and nspDBD Treatment of Jurkat T Lymphocytes}

3.1.1. COST-Jet and nspDBD Treatment Cause Comparable Reductions in Jurkat T Lymphocyte Viability

To establish a common basis for comparing the two plasma sources, we sought treatment parameters necessary to achieve a predefined biological endpoint-comparable reductions in viability. 
Jurkat cells were treated by plasma from the nspDBD [33] or the COST-Jet [34] $\left(\mathrm{He}+0.6 \% \mathrm{O}_{2}\right)$, using conditions described in previous studies (Table 1). In these studies, reduced viability was correlated with frequency for the nspDBD and treatment time for the COST-Jet; thus, we treated from $30-75 \mathrm{~Hz}$ with the nspDBD and up to $5 \mathrm{~min}$ with the COST-Jet. Cells were analyzed $24 \mathrm{~h}$ post-treatment. The propidium iodide (PI) viability assay was used to identify plasma parameters for each source that caused comparable reductions in cell viability.

Jurkat cell viability, normalized to the untreated controls (for the COST-Jet controls, cells were exposed to the feed gas only), was reduced with increasing frequency for nspDBD and increasing treatment time for the COST-Jet. A 5-min exposure to the feed gas $\left(\mathrm{He}+0.6 \% \mathrm{O}_{2}\right)$ did not affect cell viability, in agreement with other COST-Jet studies [34,35].

As shown in Figure 2, two operating conditions were identified between the two plasma sources where cell viability was comparable:

1. 2-min for the COST-Jet $(93.7 \% \pm 3.9 \%)$ and $45 \mathrm{~Hz}$ for the nspDBD $(89.8 \% \pm 10.01 \%)$

2. 4-min for the COST-Jet $(65.7 \% \pm 3.4 \%)$ and $75 \mathrm{~Hz}$ for the $\operatorname{nspDBD}(61.9 \% \pm 9.4 \%)$.

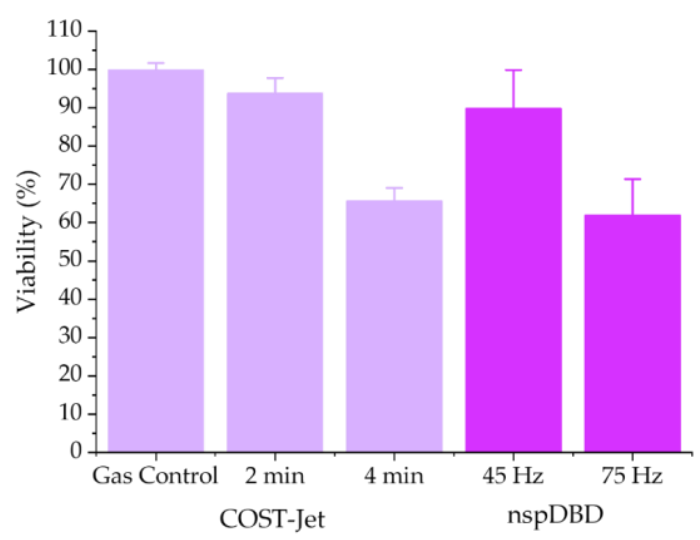

Figure 2. Viability comparison of Jurkat T lymphocytes treated with nspDBD or COST-Jet $(\mathrm{He}+0.6 \%$ $\mathrm{O}_{2}$ ). Cells were treated from $30-75 \mathrm{~Hz}$ with the nspDBD and 1-5 min with the COST-Jet. Percent viability was calculated relative to cells not exposed to plasma or feed gas. Cell loss was comparable at 2 and 4 min of COST-Jet treatment with 45 and $75 \mathrm{~Hz}$ nspDBD treatment, respectively. Viability experiments were repeated once in triplicate. The data plotted represent the mean and standard deviation.

These results demonstrated that completely different plasma devices could be operated to achieve the same biological endpoint. These two discharge conditions were used as the basis for further comparative investigations because similar responses were observed despite the fact that the cells were exposed to different magnitudes of species and conditions unique to each source (gas flow for the COST-Jet; charged species, UV radiation, and electric field for the nspDBD).

\subsubsection{Mitochondrial Superoxide Production Increases in Response to Plasma Treatment}

Additional experiments were conducted to determine if other biological endpoints were also comparable at these operating conditions. Another cellular function that is known to be affected by plasma is the triggering of intracellular oxidative stress pathways. $\mathrm{O}_{2}{ }^{-}$production by the mitochondria is an indicator of cellular oxidative stress [36,37]. To determine if there were differences in the oxidative stress induced by each device, we compared MitoSOX fluorescence in Jurkat cells treated with both plasma sources. As shown in Figure 3, cells treated with the COST-Jet and nspDBD at the same operating conditions as above had similar magnitudes of MitoSOX fluorescence. Cells responded to plasma from both sources by increasing their mitochondrial $\mathrm{O}_{2}{ }^{-}$production in a dose-dependent fashion, indicating that stress-responsive pathways were being upregulated in each case. 


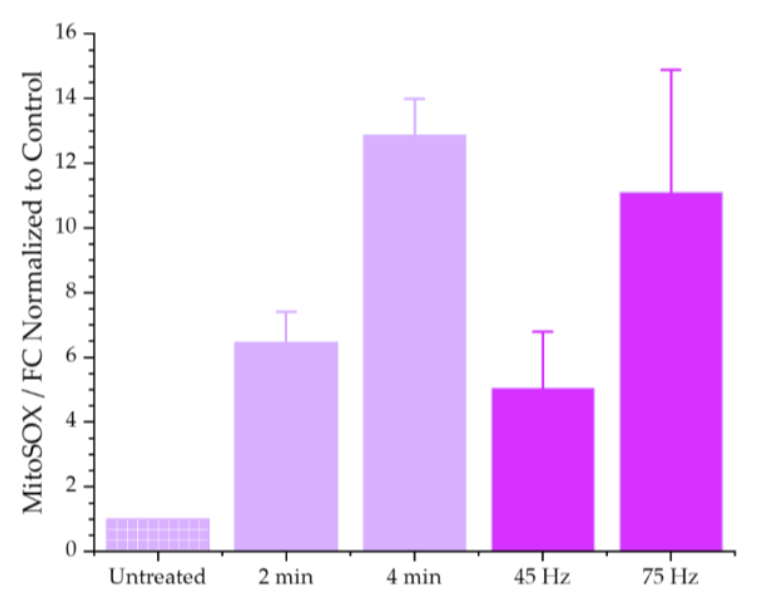

Figure 3. Mitochondrial $\mathrm{O}_{2}{ }^{-}$production in Jurkat $\mathrm{T}$ lymphocytes in response to plasma treatment. COST-Jet ( 2 and $4 \mathrm{~min}$ ) and nspDBD ( 45 and $75 \mathrm{~Hz}$ ) induced higher and comparable magnitudes of oxidative stress relative to the untreated control cells. This experiment was repeated once in triplicate. The data plotted represent the mean and standard deviation.

\subsubsection{COST-Jet and nspDBD Treatment Increase the Cell Surface Display of Ecto-CRT}

To assess a third biological response that is influenced by plasma-induced changes in cellular redox, we analyzed the cell surface display of calreticulin (ecto-CRT) on Jurkat cells after exposure to both plasma devices. Ecto-CRT is known to increase the phagocytic uptake of cells, which is a crucial step in the initiation of immune responses [38]. Generation of intracellular RONS, such as $\mathrm{O}_{2}{ }^{-}$, upon plasma exposure, has been shown to induce endoplasmic reticulum (ER) stress and cause the ER-resident chaperone protein, calreticulin, to become translocated to the cell surface [33]. Furthermore, this translocation is believed to be largely dependent on plasma-delivered short-lived species [15]. The influence of nspDBD and COST-Jet plasma exposures on ecto-CRT translocation was compared under the plasma conditions shown to produce similar reductions in cell viability (Figure 2). We found that plasma treatment increased ecto-CRT in both cases (Figure 4), possibly as a result of increased oxidative ER stress. This suggested that the unique cocktail of effectors generated by the COST-Jet affected CRT translocation, albeit perhaps through a different chemical pathway, to a degree similar to that attributed to the nspDBD.
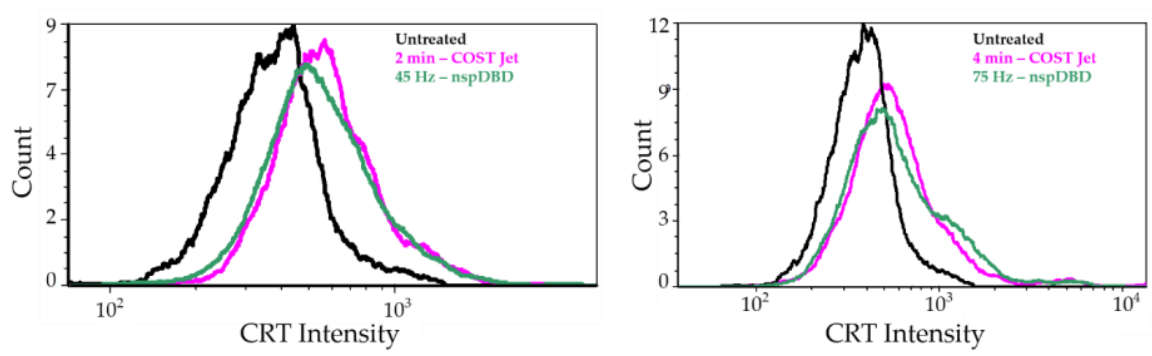

Figure 4. Expression of calreticulin (ecto-CRT) was measured $24 \mathrm{~h}$ post-treatment on Jurkat $\mathrm{T}$ lymphocytes treated at the two comparable conditions: $2 \mathrm{~min} / 45 \mathrm{~Hz}$ (Left) and $4 \mathrm{~min} / 75 \mathrm{~Hz}$ (Right). Both devices induced similar increases in the numbers of ecto-CRT-positive cells.

\subsection{Chemical Comparison and Mock Treatment Are Inaccurate Markers of Cellular Responses}

The comparable cellular responses from COST-Jet and nspDBD treatments suggested that, if the cellular stress response mechanisms were the same, the stressors generated by the plasma should be of similar magnitude. These responses have been attributed to multiple factors from plasma treatment, e.g., pulsed electric fields [39], RONS [40]. While studies have shown that CRT translocation and mitochondrial $\mathrm{O}_{2}{ }^{-}$production is stimulated by the presence of short-lived species [15], Jurkat 
T-lymphocytes are known to be sensitive to a few hundred micromolar of $\mathrm{H}_{2} \mathrm{O}_{2}$ [41], a long-lived species. To investigate the contribution of long-lived species to the biological responses observed by plasma treatment, we measured their concentration subsequent to plasma treatment and subjected the cells to these measured concentrations as a mock chemical treatment. We hypothesized that similar concentrations of $\mathrm{H}_{2} \mathrm{O}_{2}$ and $\mathrm{NO}_{2}{ }^{-}$must be produced to achieve similar biological responses. We evaluated their concentrations at both conditions ( 2 min vs. $45 \mathrm{~Hz} ; 4$ min vs. $75 \mathrm{~Hz}$ ) that caused similar reductions in viability in order to correlate the increase in solvated RONS with this biological endpoint. While nitrate $\left(\mathrm{NO}_{3}{ }^{-}\right)$is an important long-lived species to measure for characterization of liquid chemistry, it was previously shown to have an insignificant impact on cellular viability in multiple cell lines when mixed with $\mathrm{H}_{2} \mathrm{O}_{2}$ and $\mathrm{NO}_{2}{ }^{-}$[42]. Therefore, we focused our experiments on $\mathrm{H}_{2} \mathrm{O}_{2}$ and $\mathrm{NO}_{2}^{-}$.

First, we measured the long-lived species in the cell culture medium to understand the concentrations to which the cells were exposed after plasma treatment. Colorimetric assays were unaffected by time-dependent losses in reactive species since the assay reaction times ( 10 min for $\mathrm{H}_{2} \mathrm{O}_{2}$ and $30 \mathrm{~min}$ for $\mathrm{NO}_{2}^{-}$) were considerably shorter than the amount of time required for significant $\mathrm{H}_{2} \mathrm{O}_{2}$ and $\mathrm{NO}_{2}{ }^{-}$losses due to reactivity [24]. Both long-lived species were produced at higher concentrations from nspDBD treatments when compared with the COST-Jet-treated solutions (Figure 5). The concentration of $\mathrm{H}_{2} \mathrm{O}_{2}$ (Figure 5, left) and $\mathrm{NO}_{2}{ }^{-}$(Figure 5, right) increased with longer treatment times for the COST-Jet and higher frequencies for the nspDBD. In culture medium treated by the COST-Jet, an increase in exposure time resulted in increased concentrations of $\mathrm{H}_{2} \mathrm{O}_{2}(78.7$ and $103.6 \mu \mathrm{M}$ after 2 and $4 \mathrm{~min}$, respectively) and $\mathrm{NO}_{2}{ }^{-}$(3.6 and $7.1 \mu \mathrm{M}$, respectively). The nspDBD concentrations increased with frequency for both species: $187.3 \mu \mathrm{M}(45 \mathrm{~Hz})$ to $226.9 \mu \mathrm{M}(75 \mathrm{~Hz})$ for $\mathrm{H}_{2} \mathrm{O}_{2}$ and $27.8 \mu \mathrm{M}$ $(45 \mathrm{~Hz})$ to $47.9 \mu \mathrm{M}(75 \mathrm{~Hz})$ for $\mathrm{NO}_{2}{ }^{-}$. These concentrations in the medium were much higher than those reported previously in deionized water [11,14], which was inconsistent with the understanding that cell culture medium would buffer long-lived species production in the liquid due to reactions between plasma-generated short-lived predecessors (such as $\mathrm{OH}$ and $\mathrm{NO}$ ) and organic compounds. We repeated the measurements in DI water to show that our measurements were consistent with those reported in the literature for both devices:

1. Concentrations of $\mathrm{H}_{2} \mathrm{O}_{2}$ in DI water (6.49 and $17.49 \mu \mathrm{M}$ after 2 and $4 \mathrm{~min}$, respectively) and $\mathrm{NO}_{2}{ }^{-}$ (1.15 and $2.01 \mu \mathrm{M}$, respectively) for the COST-Jet [21,43].

2. For the nspDBD [14], the $\mathrm{H}_{2} \mathrm{O}_{2}$ concentration in DI water increased from $109.6 \mu \mathrm{M}$ to $150.1 \mu \mathrm{M}$ and $\mathrm{NO}_{2}{ }^{-}$concentrations from $3.9 \mu \mathrm{M}$ to $9.01 \mu \mathrm{M}$ when the frequency was increased from 45 to $75 \mathrm{~Hz}$.
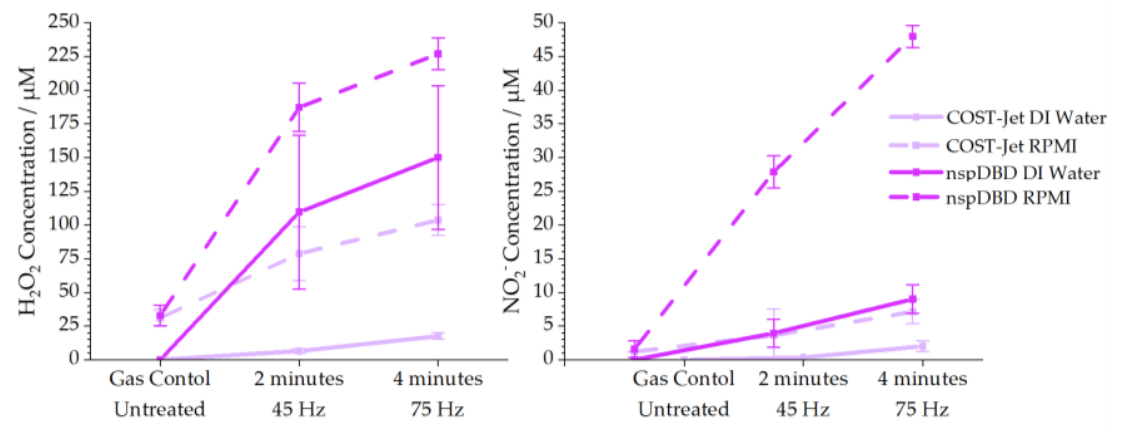

Figure 5. Concentrations of $\mathrm{H}_{2} \mathrm{O}_{2}$ (Left) and $\mathrm{NO}_{2}{ }^{-}$(Right) in DI water (solid line) or RPMI (Roswell Park Memorial Institute) supplemented with 10\% fetal bovine serum (FBS) and 1\% penicillin/streptomycin $(\mathrm{P} / \mathrm{S})$ (dashed line) post plasma treatment. The gas control and untreated $\mathrm{H}_{2} \mathrm{O}_{2}$ measurement indicate the medium itself is detected by the peroxide kit used. These experiments were repeated once, and the data plotted represent the mean and standard deviation. 
The organic and oxidizable components of the culture medium, as well as the higher $\mathrm{pH}$, should buffer the oxidative capacity of the plasma-generated RONS and reduce their concentrations. The chemical pathways for $\mathrm{H}_{2} \mathrm{O}_{2}$ formation from plasma treatment are described through the following mechanisms [44]:

$$
\begin{gathered}
\mathrm{OH}+\mathrm{OH} \rightarrow \mathrm{H}_{2} \mathrm{O}_{2}, \\
\mathrm{HO}_{2}+\mathrm{H}_{2} \mathrm{O}+\mathrm{O}_{2}{ }^{-} \rightarrow \mathrm{O}_{2}+\mathrm{OH}^{-}+\mathrm{H}_{2} \mathrm{O}_{2}, \\
2 \mathrm{HO}_{2} \rightarrow \mathrm{O}_{2}+\mathrm{H}_{2} \mathrm{O}_{2},
\end{gathered}
$$

while a significant portion of $\mathrm{H}_{2} \mathrm{O}_{2}$ produced during plasma treatment is in the gas phase and is subsequently solvated, there is also the possibility of forming $\mathrm{H}_{2} \mathrm{O}_{2}$ in the liquid phase [29]. The pathway depicted by reaction (1) forms $\mathrm{H}_{2} \mathrm{O}_{2}$ at the liquid interface from plasma-generated $\mathrm{OH}$. The latter two reactions $(2,3)$ mainly occur in the bulk liquid as secondary chemistry. $\mathrm{H}_{2} \mathrm{O}_{2}, \mathrm{OH}$, and $\mathrm{O}_{2}{ }^{-}$ will react readily with the medium components, which should significantly reduce the concentration of $\mathrm{H}_{2} \mathrm{O}_{2}$ formed by reactions (1) and (2). However, the higher concentrations observed in the medium suggest the formation of organic peroxides from both plasma sources. This has been previously hypothesized by Privat-Maldonado et al. [45], based on the reaction between solvated ozone $\left(\mathrm{O}_{3}\right)$ and organic compounds [46]. Experimentally, it was shown by Hefny et al. that $\mathrm{O}_{3}$ and $\mathrm{O}$ produced using the COST-Jet $\left(0.6 \% \mathrm{O}_{2}\right.$ admixture) increased the $\mathrm{H}_{2} \mathrm{O}_{2}$ concentration in DI water if phenol was present [47]. For our investigation, the $\mathrm{O}_{\text {and }} \mathrm{O}_{3}$ produced by the COST-Jet [47,48] and RONS produced from the nspDBD at ambient conditions [49] could solvate and produce higher concentrations of $\mathrm{H}_{2} \mathrm{O}_{2}$ in the medium in comparison with DI water.

The considerably higher production of $\mathrm{H}_{2} \mathrm{O}_{2}$ and $\mathrm{NO}_{2}{ }^{-}$of nspDBD treatment showed the stronger oxidative environment of the nspDBD in comparison to the COST-Jet. The $\mathrm{H}_{2} \mathrm{O}_{2}$ concentrations from these treatments alone should adversely impact viability [41]. However, the biological responses of Jurkat cells to both treatments were comparable under these exposure conditions. These cells, which were sensitive to oxidation, exhibited similar responses when exposed to two different plasma chemistries of differing oxidative magnitude. We tested the cellular response to $\mathrm{H}_{2} \mathrm{O}_{2}$ and $\mathrm{NO}_{2}{ }^{-}$, both alone and in combination, as a mock treatment to understand if the long-lived species had the oxidative impact to affect the cells. In lieu of plasma treatment, these cells were exposed to exogenously added concentrations of $\mathrm{H}_{2} \mathrm{O}_{2}$ and $\mathrm{NO}_{2}{ }^{-}$(Table 2), as measured in DI water. The concern with using the high nspDBD cell culture concentrations was that it would reduce Jurkat viability to zero, leading to results that would be difficult to detect and would not highlight responses due to small changes in concentration. The measured nspDBD DI water concentrations were comparable to the concentrations known to induce cellular responses in Jurkat. Therefore, these concentrations were added to cells in culture medium and incubated for $24 \mathrm{~h}$. This mock treatment would not be comparable to the plasma treatment directly but rather an indication of how Jurkat cells reacted to the oxidative environment.

Table 2. Mock Treatment Concentrations.

\begin{tabular}{ccc}
\hline Treatment Condition & $\mathbf{H}_{\mathbf{2}} \mathbf{O}_{\mathbf{2}}(\boldsymbol{\mu M})$ & $\mathbf{N O}_{2}{ }^{-}(\mu \mathbf{M})$ \\
\hline COST-Jet: 2 min & 6.50 & 1.15 \\
COST-Jet: $4 \mathrm{~min}$ & 17.35 & 2.01 \\
nspDBD: $45 \mathrm{~Hz}$ & 108.78 & 3.92 \\
nspDBD: $75 \mathrm{~Hz}$ & 149.93 & 9.01 \\
\hline
\end{tabular}

The viability and oxidative stress responses of Jurkat cells are shown in Figure 6, with the results obtained after plasma treatment as a benchmark. Mock treatment at the COST-Jet conditions did not reduce cell viability to the degree caused by plasma treatment (Figure $6 \mathrm{a}$,d), showing that $\mathrm{H}_{2} \mathrm{O}_{2}$ concentrations below $20 \mu \mathrm{M}$ did not adversely affect the cells. The $\mathrm{H}_{2} \mathrm{O}_{2}$ concentrations greater than $100 \mu \mathrm{M}$ induced higher magnitudes of cell death than the nspDBD conditions (Figure $6 \mathrm{a}, \mathrm{d}$ ). These results supported previous literature that demonstrated $\mathrm{H}_{2} \mathrm{O}_{2}$ concentrations above $100 \mu \mathrm{M}$ induced 
cellular arrest in Jurkat cells [41]. This clearly showed, as described above, that the higher oxidative environment due to the high concentration of $\mathrm{H}_{2} \mathrm{O}_{2}$ adversely affected the Jurkat cells. Added $\mathrm{NO}_{2}{ }^{-}$ at concentrations measured from the nspDBD and COST-Jet treatments did not have any effects on cell viability. In addition, when $\mathrm{NO}_{2}{ }^{-}$was combined with $\mathrm{H}_{2} \mathrm{O}_{2}$, the observed loss in viability was comparable to cells treated with $\mathrm{H}_{2} \mathrm{O}_{2}$ alone. These observations suggested that $\mathrm{NO}_{2}{ }^{-}$did not influence the cell viability directly or through reaction with $\mathrm{H}_{2} \mathrm{O}_{2}$.
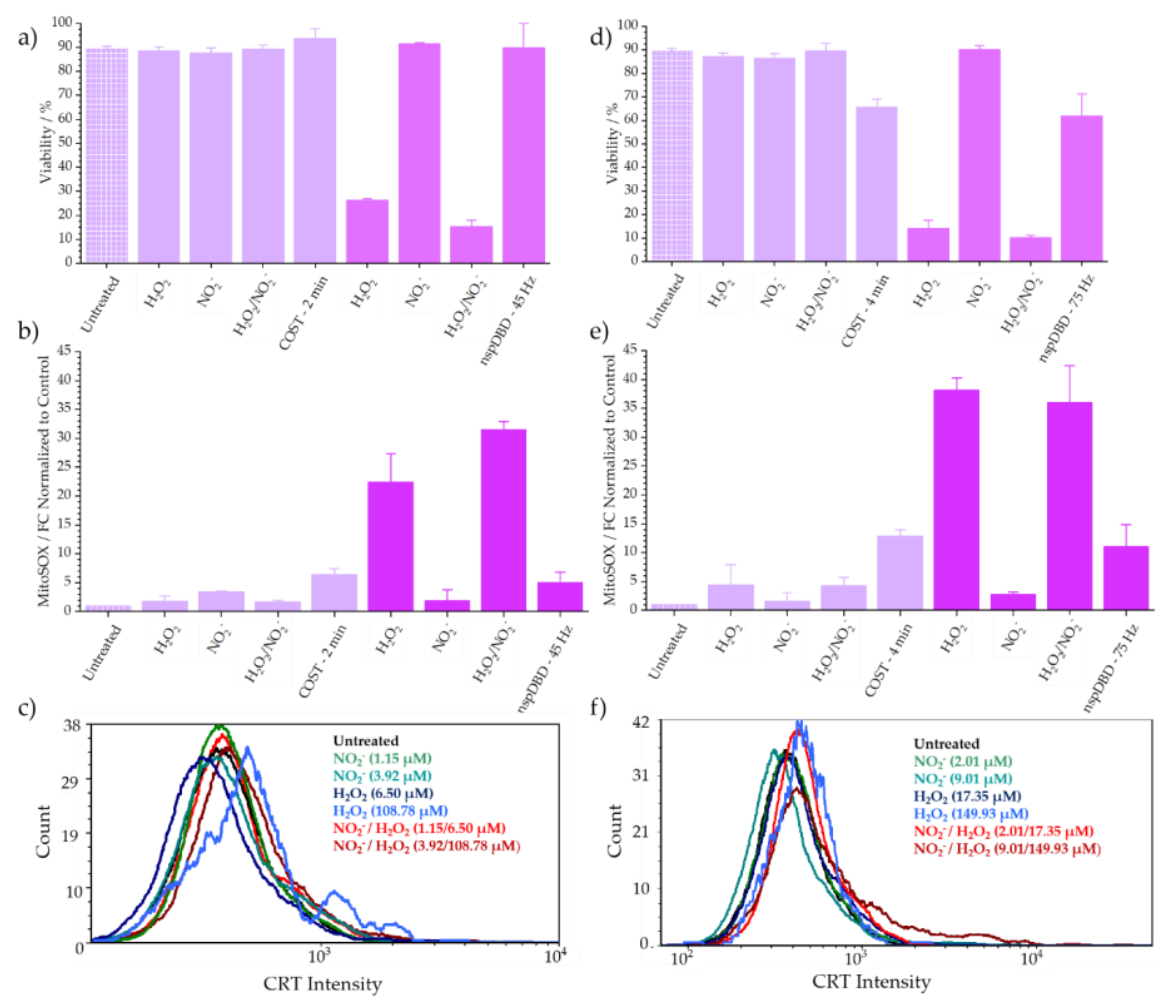

Figure 6. Exogenous addition of $\mathrm{H}_{2} \mathrm{O}_{2}$ elicited cellular responses from Jurkat $\mathrm{T}$ lymphocytes at the two comparable conditions of $2 \mathrm{~min} / 45 \mathrm{~Hz}(\mathbf{a}-\mathbf{c})$ and $4 \mathrm{~min} / 75 \mathrm{~Hz}(\mathbf{d}-\mathbf{f})$. Mock treatment reduced viability and stimulated mitochondrial $\mathrm{O}_{2}{ }^{-}$production above the untreated control only at $\mathrm{H}_{2} \mathrm{O}_{2}$ concentrations above $100 \mu \mathrm{M}$. (d) There were no changes in ecto-CRT responses to mock treatments. The mock treatment experiments were performed once in triplicate. The data represent the mean and standard deviation.

Mitochondrial activity was stimulated by $\mathrm{H}_{2} \mathrm{O}_{2}$ alone and in combination with $\mathrm{NO}_{2}{ }^{-}$at the nspDBD conditions in comparison to the untreated control, as shown in Figure $6 \mathrm{~b}$,e. $\mathrm{H}_{2} \mathrm{O}_{2}$ is a potent oxidizer and is well known to induce mitochondrial stress at concentrations as low as 100 $\mu \mathrm{M}$ [50]. $\mathrm{NO}_{2}{ }^{-}$alone had no discernable effect on mitochondrial $\mathrm{O}_{2}{ }^{-}$production for either of the mock treatments. The significant increase in mitochondrial activity due to the addition of exogenous $\mathrm{H}_{2} \mathrm{O}_{2}$ in comparison with the plasma-treated cells was indicative of the strong oxidative environment. The $\mathrm{H}_{2} \mathrm{O}_{2}$ concentration produced by the COST-Jet for both conditions was too low to stimulate mitochondrial $\mathrm{O}_{2}^{-}$above the untreated control.

The effect of mock treatment on ecto-CRT expression was evaluated on Jurkat cells incubated with the RONS for $24 \mathrm{~h}$. As seen in Figure $6 \mathrm{c}$,f, only the nspDBD concentration of $\mathrm{H}_{2} \mathrm{O}_{2}$ produced a slight rightward shift and a second brighter peak in fluorescence. This was due to the higher numbers of dead and dying cells, as seen in Figure 6a,d. None of the other mock treatments produced an increase in ecto-CRT expression, clearly indicating that stable chemistry is unable to trigger necessary biological pathways that cause CRT translocation. 
Our results demonstrated that, for Jurkats, mock treatment was not a good indicator of the role plasma components have in triggering cellular responses. The $\mathrm{H}_{2} \mathrm{O}_{2}$ concentrations produced by both devices should trigger stronger cellular responses. The reduced toxicity of $\mathrm{H}_{2} \mathrm{O}_{2}$ during plasma treatment was likely due to secondary reactions in the medium itself. Components in the medium and the cells themselves that offer oxidizable targets for plasma-generated species (both short and long-lived) altered the concentrations of individual species. Several investigations focus on the reactions between individual amino acids and other organic compounds, such as reactive sulfur species with plasma-generated RONS [51-53]. These compounds reduce the amount of plasma-generated species in the liquid by reacting with them. However, subsequent reactions can lead to increases in the overall inventory of RONS in the solution. Bruno et al. showed that cysteine alone could reduce $\mathrm{H}_{2} \mathrm{O}_{2}$ produced by the kINPen while increasing reactive nitrogen species (RNS) [52]. As Privat-Maldonado et al. showed through electroparamagnetic spectroscopy, there are also increases in the concentrations of short-lived species after plasma treatment of cell culture medium [45], which are precursors to these long-lived species [44]. The biological effects of the short-lived species on cellular responses are well-documented in plasma literature $[15,35,54]$. These initiating molecules are absent during mock treatments, which is why we did not observe similar cellular responses and GSH modifications to plasma treatment. Without the short-lived species and the organic compounds they modify, our mock treatment with exogenous $\mathrm{H}_{2} \mathrm{O}_{2}$ and $\mathrm{NO}_{2}{ }^{-}$is not representative of the actual contribution these long-lived species have during plasma treatment.

\subsection{GSH Modifications Unique to Plasma Source Indicate the Stressors and the Potential for Cellular Response Present During Plasma Treatment}

The data presented thus far indicated a lack of correlation between the relatively easy-to-measure long-lived species and cellular responses. The results from mock treatments demonstrated that using the measured RONS as an indicator of biological responses to plasma treatment was not sufficient. Therefore, there was a need for a method that is a true reflection of plasma parameters and the ensuing biological outcomes. In subsequent experiments, we expanded on the use of GSH as an indicator of how plasma might impact the cellular redox system, as proposed by Klinkhammer et al. [23], and related our measured biological responses to measured GSH modifications. GSH modifications after plasma or mock treatment were analyzed to address their correlation with the observed biological responses.

The specific modifications to GSH exposed to plasma treatment elucidated the possible reactive species near the molecule. Similar to previous reports on microsecond pulsed DBD-treated GSH [23], nspDBD plasma treatment caused a decrease in the intensity of the peak at $2560 \mathrm{~cm}^{-1}$ and an increase of the $1045 \mathrm{~cm}^{-1}$ peak when compared to the untreated GSH (Figure 7). These wavenumbers corresponded to the $\mathrm{S}-\mathrm{H}(\vee(\mathrm{S}-\mathrm{H}))$ and the $\mathrm{S}=\mathrm{O}(\vee(\mathrm{S}=\mathrm{O}))$ vibrational stretching modes, respectively, and indicated that S-H bonds were oxidized. Molecular dynamic (MD) simulations have previously shown that $\mathrm{H}_{2} \mathrm{O}_{2}$ did not initialize the oxidation of glutathione [23]. The model predicted that $\mathrm{OH}$ was the initiator of the reaction by forming the glutathione radical $\left(-S^{\bullet}\right)$, which is known to react quickly with $\mathrm{H}_{2} \mathrm{O}_{2}$ and form glutathione sulfenic acid (GSOH) in biological systems [55]. The MD simulations also showed that glutathione radicals could react with $\mathrm{OH}, \mathrm{NO}$, or another glutathione radical to form GSOH, S-nitrosoglutathione (GSNO), and glutathione disulfide (GSSG), respectively, in the liquid phase [23]. The presence of $\mathrm{GSOH}$ and the $v(\mathrm{~S}=\mathrm{O})$ band in our nspDBD-treated samples indicated the presence of $\mathrm{OH}$ and subsequent oxidation to form higher oxidation states. These states were $\mathrm{GSOH}, \mathrm{GSO}_{2} \mathrm{H}$, and $\mathrm{GSO}_{3} \mathrm{H}$, the latter two corresponding to the $v(\mathrm{~S}=\mathrm{O})$ band. Klinkhammer et al. observed that significantly more $\mathrm{GSO}_{3} \mathrm{H}$ than $\mathrm{GSO}_{2} \mathrm{H}$ was produced by DBD treatment through mass spectrometry [23]. This type of oxidation is irreversible in biological systems [56], indicating the highly oxidative environment of microsecond pulse DBD treatment, as shown by Klinkhammer et al. [23], as well as that of the nspDBD treatment, as presented here. 


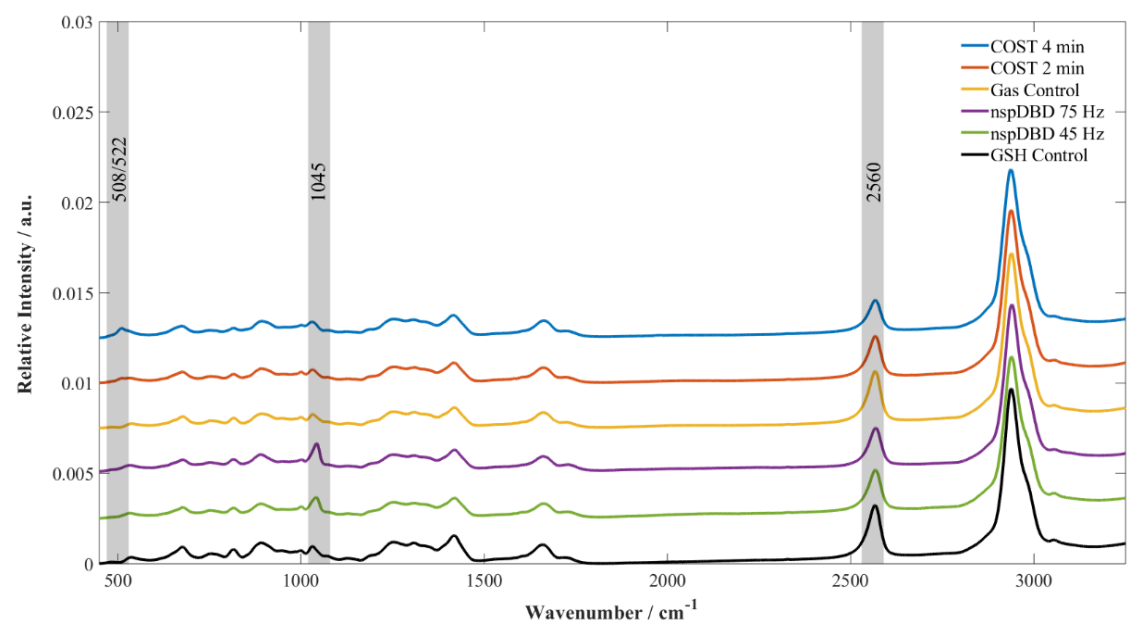

Figure 7. Raman spectra of glutathione (GSH) in deionized water post plasma treatment with the nspDBD and COST-Jet. The main observations from both sources were reduced S-H stretching (2560 $\mathrm{cm}^{-1}$ ) that was further reduced after increased plasma treatment. Interestingly, increased S-O stretching $\left(1045 \mathrm{~cm}^{-1}\right)$ was observed only for the nspDBD treatment, whereas the COST-Jet-treated GSH showed increased S-S stretching $\left(508 / 522 \mathrm{~cm}^{-1}\right)$, indicating the formation of GSSG. These differences between the nspDBD and the COST-Jet indicated the different magnitudes of oxidation between the two treatments.

Although the COST-Jet treated samples reduced the $v(\mathrm{~S}-\mathrm{H})$ band similar to the nspDBD-treated samples, an increase of the $v(\mathrm{~S}=\mathrm{O})$ mode was not observed. Instead, an increase of the $v(\mathrm{~S}-\mathrm{S})$ band was observed in the COST-Jet-treated samples, which was more pronounced for the 4-min treatment. In the case of the COST-Jet, there was little $\mathrm{OH}$ generated with an admixture of $\mathrm{O}_{2}$. Instead, production of $\mathrm{O}, \mathrm{O}_{3}$, and singlet oxygen $\left(\mathrm{O}_{2}\left(\mathrm{a}^{1} \mathrm{Ag}\right)\right)$ was magnified $[48,57,58]$. It was likely that the dominant mechanism to form the glutathione radical was through $\mathrm{H}$ abstraction by $\mathrm{O}$ rather than $\mathrm{OH}$. However, there was not enough oxidation to form $\mathrm{GSO}_{3} \mathrm{H}$, as indicated by the absence of the $v(\mathrm{~S}=\mathrm{O})$ mode. While this showed $\mathrm{GSO}_{3} \mathrm{H}$ was not produced, the lower oxidation states might still be formed, indicating a less oxidative environment. This was expected between the two treatments since the end product of the ROS, $\mathrm{H}_{2} \mathrm{O}_{2}$, was lower for COST-Jet treatments.

The differences in GSH modifications between the COST-Jet and nspDBD suggested there might be different pathways of inducing oxidative stress and reducing the viability of Jurkat cells. Oxidation of the glutathione radical leads to the formation $\mathrm{GSOH}$ [55]. Further oxidation forms glutathione sulfinic acid $\left(\mathrm{GSO}_{2} \mathrm{H}\right)$ and glutathione sulfonic acid $\left(\mathrm{GSO}_{3} \mathrm{H}\right)$, whereas GSNO or GSSG may occur in the absence of an oxidative environment. The lack of the $v(\mathrm{~S}=\mathrm{O})$ mode in COST-Jet-treated samples suggested that in order to achieve the same biological responses, there must be another mechanism of oxidative stress that is unique to the COST-Jet source. The Raman spectra showed the formation of GSSG. The disulfide bond would form in a reaction between the glutathione radical and GSH. Both the sulfenic modification and glutathionylation (a disulfide bond between GSH and another protein) were shown by others to adversely impact Jurkat cells [41]. $\mathrm{H}_{2} \mathrm{O}_{2}$ added exogenously (at $200 \mu \mathrm{M}$ ) led to the irreversible oxidation of GSH and other proteins in the antioxidant systems that led to cellular arrest in Jurkat cells. The observed GSH modifications from nspDBD and COST-Jet treatments showed that there was the potential to induce these reactions in cell-associated GSH. Therefore, while the biological endpoint post plasma treatment was similar, the protein modifications and mechanisms for oxidative stress might be different between the two plasma sources.

Next, we assessed if mock treatment-induced modifications were distinguishable from plasma treatment. We exogenously added the concentrations of RONS, shown in Table 2, to solutions of GSH in DI water. We plotted the analyzed Raman spectra of GSH in the presence of $\mathrm{H}_{2} \mathrm{O}_{2}, \mathrm{NO}_{2}{ }^{-}$, and the $\mathrm{H}_{2} \mathrm{O}_{2} / \mathrm{NO}_{2}{ }^{-}$combination and compared them to spectra generated by plasma treatments (Figure 8, top row). The spectra of the nspDBD mock treatment showed that $\mathrm{H}_{2} \mathrm{O}_{2}$ and the $\mathrm{H}_{2} \mathrm{O}_{2} / \mathrm{NO}_{2}{ }^{-}$ 
combination reduced the $v(\mathrm{~S}-\mathrm{H})$ comparably to the plasma-treated samples. However, an increase in $v(\mathrm{~S}=\mathrm{O})$ was not observed. Instead, an increase in the $v(\mathrm{~S}-\mathrm{S})$ band was observed, which suggested slight oxidation of GSH in contrast with the higher oxidation of the nspDBD-treated samples. The $\mathrm{NO}_{2}{ }^{-}$-treated samples did not modify GSH when compared to the untreated control. Only nspDBD plasma treatment reduced the $v(\mathrm{~S}-\mathrm{H})$ band and increased the $v(\mathrm{~S}=\mathrm{O})$ band. Taken together, there was not sufficient $\mathrm{OH}$ or $\mathrm{O}$ from the mock treatment to initiate the reaction with GSH and reduce the $v$ (S-H) band.

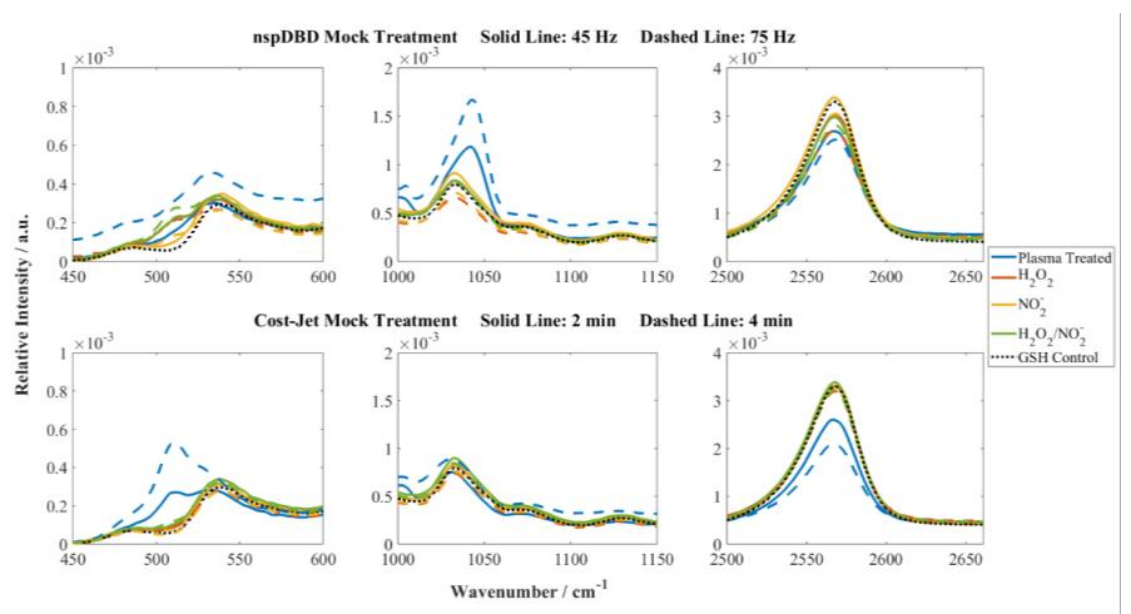

Figure 8. Raman spectra analysis of plasma-treated GSH showed more pronounced peaks than mock treatment. GSH was mixed with $\mathrm{H}_{2} \mathrm{O}_{2}, \mathrm{NO}_{2}{ }^{-}$, or their combination. The spectra were plotted against their corresponding plasma treatment counterparts. The spectra were centered on the observed modifications from plasma treatment: increased in the $v(\mathrm{~S}-\mathrm{S})\left(508 / 522 \mathrm{~cm}^{-1}\right)$ and $v(\mathrm{~S}=\mathrm{O})\left(1045 \mathrm{~cm}^{-1}\right)$ bands with a decrease in the $v(\mathrm{~S}-\mathrm{H})\left(2560 \mathrm{~cm}^{-1}\right)$ band. For both the nspDBD and the COST-Jet, stronger plasma treatment resulted in more pronounced modifications. (Top Row) The nspDBD treatment of GSH resulted in a decrease in the $v(\mathrm{~S}-\mathrm{H})$ band and an increase in the $v(\mathrm{~S}=\mathrm{O})$ band with no change in the $v(\mathrm{~S}-\mathrm{S})$ band. The $\mathrm{H}_{2} \mathrm{O}_{2}$ only and the combined mock treatment at these conditions reduced the $v(\mathrm{~S}-\mathrm{H})$ band with a slight increase in the $v(\mathrm{~S}-\mathrm{S})$ band, which indicated slight oxidation of the GSH. There was no discernable difference in modifications between the $\mathrm{NO}_{2}{ }^{-}$treatment when compared with the untreated control. (Bottom Row) The COST-Jet-treated samples showed a decrease in the $v$ $(\mathrm{S}-\mathrm{H})$ band and an increase in the $v(\mathrm{~S}-\mathrm{S})$ band. There was no increase in the $v(\mathrm{~S}=\mathrm{O})$ band. The mock treatment samples did not modify the GSH when compared to the control.

For COST-Jet treatments (Figure 8, bottom row), the decrease in the $v(\mathrm{~S}-\mathrm{H})$ band was observed only in plasma-treated samples. The concentrations of $\mathrm{H}_{2} \mathrm{O}_{2}, \mathrm{NO}_{2}{ }^{-}$, and the $\mathrm{H}_{2} \mathrm{O}_{2} / \mathrm{NO}_{2}{ }^{-}$combination were not sufficient to induce measurable oxidation of the $\mathrm{S}-\mathrm{H}$ bond. This indicated that the observed modifications from plasma treatment-the decrease of $v(\mathrm{~S}-\mathrm{H})$ and the increase of the $v(\mathrm{~S}-\mathrm{S})$ band-required short-lived species like $\mathrm{O}$ and $\mathrm{OH}$. The absence of the increase in $v$ (S-S) and decrease in $v(\mathrm{~S}-\mathrm{H})$ bands from mock treatment indicated that other plasma components were required to induce these modifications and might be needed to induce biological responses.

\section{Discussion}

This study provided initial evidence that GSH modifications caused by plasma treatment might be used as markers of potential cellular responses. These modifications were due to the myriad plasma components that modify it. The presence and increase of $v(\mathrm{~S}-\mathrm{S})$ or $v(\mathrm{~S}=\mathrm{O})$ bands with a decrease in the $v(\mathrm{~S}-\mathrm{H})$ band correlated with the biological responses of Jurkat $\mathrm{T}$ lymphocytes to COST-Jet and nspDBD treatment, respectively. In addition, stronger plasma treatment for both sources increased the magnitude of these modifications and further affected the biological responses, showing that GSH modifications could potentially be scalable and be indicative of the magnitudes of RONS present. The 
absence of these modifications in mock-treated samples strongly suggested the role of the initiator molecules- $\mathrm{O}$ and/or $\mathrm{OH}-$ in the biological responses.

The contrast between observed cellular responses from plasma and mock treatment and the measured chemical concentrations indicated that the interactions between the plasma-generated RONS and the medium components drove the chemistry that the cells experience. Concentrations of $\mathrm{H}_{2} \mathrm{O}_{2}$ measured in medium alone from both sources would induce stronger cellular responses than plasma treatment at the corresponding conditions. RONS generated by plasma treatment and medium components must react and reduce the toxicity of $\mathrm{H}_{2} \mathrm{O}_{2}$ alone in order to achieve the observed cellular responses with the measured medium $\mathrm{H}_{2} \mathrm{O}_{2}$ concentrations. Some of these reactions may form species that cause harm to the cells themselves, such as DNA strand breaks or have other biological outcomes [11,51-53,58].

A unique feature of using GSH as a marker of the potency of plasma treatment is the scalability with plasma treatment parameters. Longer treatment times for the COST-Jet or higher frequencies for the nspDBD resulted in more significant modifications, which supported previous literature that showed similar trends using sulfur compounds [11,22,23]. As shown in this study, these stronger treatments triggered higher magnitudes of cellular responses. The treatment of GSH solutions as a model for treatment targets elucidated the roles of short-lived species, as shown in other studies using phenol $[24,59]$, and their combination with long-lived species. Our results showed there is potential to investigate $\mathrm{O}$ for the COST-Jet and $\mathrm{OH}$ for the nspDBD as initiator molecules for the biological responses. This work expanded on comparing a DBD with an APPJ by investigating how the different chemistry produced can lead to similar biological responses [14].

The case for GSH as a marker for treatment outcomes in plasma medicine can be made because these modifications can be correlated to possible cellular effects in redox biology literature $[60,61]$. Cellular responses to plasma treatment are cell type-dependent, which means a specific modification will not necessarily indicate a specific biological outcome for different types of cells. The development of GSH as a marker would allow plasma medicine researchers to explore translational opportunities without the need for cell culture in early exploratory experiments. Plasma sources like DBDs and APPJs could potentially be compared using indicator modifications that serve as benchmarks for other sources used in the plasma medicine field. Of course, a more robust set of tests needs to be completed with different cell lines, plasma devices, and cellular responses to achieve this goal and correlate plasma parameters to biological outcomes signaled by GSH modifications.

\section{Conclusions}

This study demonstrated the potential for correlations between modifications to markers, such as GSH, and biological outcomes. The markers themselves highlight the existence of short-lived species through defined chemical reactions that result in the modifications from plasma-derived chemistry. Since the modifications scale with the cellular responses and plasma treatment magnitude, these markers could be used as a way to compare plasma devices and their potential for biological outcomes.

Author Contributions: Conceptualization, P.R.; methodology, P.R., H.M., V.M., B.M. and K.S.; software, D.T. and K.S.; validation, B.M., H.M., D.T., L.D. and K.B.; formal analysis, P.R., H.M. and D.T.; investigation, P.R., H.M., B.M., D.T., K.B. and L.D.; resources, K.S., V.M. and F.K.; data curation, P.R., D.T. and H.M.; writing-original draft preparation, P.R.; writing—review and editing, P.R., H.M., B.M., D.T., L.D., K.B., F.C.K., V.M. and K.S.; visualization, P.R. and H.M.; supervision, F.C.K., V.M. and K.S.; All authors have read and agreed to the published version of the manuscript.

Funding: This research received no external funding.

Acknowledgments: The authors acknowledge Eric Gebski and Rita Esposito for their assistance in performing cellular assays.

Conflicts of Interest: The authors declare no conflict of interest. 


\section{References}

1. Bekeschus, S.; Schmidt, A.; Weltmann, K.-D.; von Woedtke, T. The plasma jet kINPen-A powerful tool for wound healing. Clin. Plasma Med. 2016, 4, 19-28. [CrossRef]

2. Brullé, L.; Vandamme, M.; Riès, D.; Martel, E.; Robert, E.; Lerondel, S.; Trichet, V.; Richard, S.; Pouvesle, J.-M.; Le Pape, A. Effects of a non thermal plasma treatment alone or in combination with gemcitabine in a MIA PaCa2-luc orthotopic pancreatic carcinoma model. PLoS ONE 2012, 7, e52653. [CrossRef] [PubMed]

3. Graves, D.B. The emerging role of reactive oxygen and nitrogen species in redox biology and some implications for plasma applications to medicine and biology. J. Phys. D Appl. Phys. 2012, 45, 263001. [CrossRef]

4. Lin, A.; Truong, B.; Patel, S.; Kaushik, N.; Choi, E.H.; Fridman, G.; Fridman, A.; Miller, V. Nanosecond-Pulsed DBD Plasma-Generated Reactive Oxygen Species Trigger Immunogenic Cell Death in A549 Lung Carcinoma Cells through Intracellular Oxidative Stress. Int. J. Mol. Sci. 2017, 18, 966. [CrossRef]

5. Korolev, Y.D.; Frants, O.B.; Landl, N.V.; Suslov, A.I. Low-current plasmatron as a source of nitrogen oxide molecules. IEEE Trans. Plasma Sci. 2012, 40, 2837-2842. [CrossRef]

6. Jiang, Y.; Sokorai, K.; Pyrgiotakis, G.; Demokritou, P.; Li, X.; Mukhopadhyay, S.; Jin, T.; Fan, X. Cold plasma-activated hydrogen peroxide aerosol inactivates Escherichia coli O157: H7, Salmonella Typhimurium, and Listeria innocua and maintains quality of grape tomato, spinach and cantaloupe. Int. J. Food Microbiol. 2017, 249, 53-60. [CrossRef]

7. Kruszelnicki, J.; Lietz, A.M.; Parsey, G.; Mohades, S.; Kushner, M.J. Consequences of Environmental Factors in Plasma Treatment of Liquids, Tissues and Materials. Clin. Plasma Med. 2018, 9, 2. [CrossRef]

8. Lietz, A.M.; Kushner, M.J. Air plasma treatment of liquid covered tissue: Long timescale chemistry. J. Phys. D Appl. Phys. 2016, 49, 425204. [CrossRef]

9. Norberg, S.A.; Parsey, G.M.; Lietz, A.M.; Johnsen, E.; Kushner, M.J. Atmospheric pressure plasma jets onto a reactive water layer over tissue: Pulse repetition rate as a control mechanism. J. Phys. D Appl. Phys. 2018, 52, 015201. [CrossRef]

10. Lu, X.; Naidis, G.; Laroussi, M.; Reuter, S.; Graves, D.; Ostrikov, K. Reactive species in non-equilibrium atmospheric-pressure plasmas: Generation, transport, and biological effects. Phys. Rep. 2016, 630, 1-84. [CrossRef]

11. Lackmann, J.-W.; Bruno, G.; Jablonowski, H.; Kogelheide, F.; Offerhaus, B.; Held, J.; Schulz-von der Gathen, V.; Stapelmann, K.; von Woedtke, T.; Wende, K. Nitrosylation vs. oxidation-How to modulate cold physical plasmas for biological applications. PLoS ONE 2019, 14, e0216606. [CrossRef] [PubMed]

12. Bekeschus, S.; Kolata, J.; Winterbourn, C.; Kramer, A.; Turner, R.; Weltmann, K.D.; Bröker, B.; Masur, K. Hydrogen peroxide: A central player in physical plasma-induced oxidative stress in human blood cells. Free Radic. Res. 2014, 48, 542-549. [CrossRef] [PubMed]

13. Yan, D.; Xiao, H.; Zhu, W.; Nourmohammadi, N.; Zhang, L.G.; Bian, K.; Keidar, M. The role of aquaporins in the anti-glioblastoma capacity of the cold plasma-stimulated medium. J. Phys. D Appl. Phys. 2017, 50, 055401. [CrossRef]

14. Bekeschus, S.; Lin, A.; Fridman, A.; Wende, K.; Weltmann, K.-D.; Miller, V. A Comparison of Floating-Electrode DBD and kINPen Jet: Plasma parameters to achieve similar growth reduction in colon cancer cells under standardized conditions. Plasma Chem. Plasma Process. 2018, 38, 1-12. [CrossRef]

15. Lin, A.; Gorbanev, Y.; De Backer, J.; Van Loenhout, J.; Van Boxem, W.; Lemière, F.; Cos, P.; Dewilde, S.; Smits, E.; Bogaerts, A. Non-Thermal Plasma as a Unique Delivery System of Short-Lived Reactive Oxygen and Nitrogen Species for Immunogenic Cell Death in Melanoma Cells. Adv. Sci. 2019, 6, 1802062. [CrossRef]

16. Wende, K.; Williams, P.; Dalluge, J.; Gaens, W.V.; Aboubakr, H.; Bischof, J.; Woedtke, T.V.; Goyal, S.M.; Weltmann, K.-D.; Bogaerts, A.; et al. Identification of the biologically active liquid chemistry induced by a nonthermal atmospheric pressure plasma jet. Biointerphases 2015, 10, 029518. [CrossRef]

17. Hensel, K.; Kučerová, K.; Tarabová, B.; Janda, M.; Machala, Z.; Sano, K.; Mihai, C.T.; Ciorpac, M.; Gorgan, L.D.; Jijie, R.; et al. Effects of air transient spark discharge and helium plasma jet on water, bacteria, cells, and biomolecules. Biointerphases 2015, 10, 029515. [CrossRef]

18. Mann, M.S.; Schnabel, U.; Weihe, T.; Weltmann, K.-D.; von Woedtke, T. A reference technique to compare the antimicrobial properties of atmospheric pressure plasma sources. Plasma Med. 2015, 5, 27-47. [CrossRef] 
19. Steuer, A.; Schmidt, A.; Laboha, P.; Babica, P.; Kolb, J.F. Transient Suppression of Gap Junctional Intercellular Communication After Exposure to 100-Nanosecond Pulsed Electric Fields. Bioelectrochemistry 2016, 112, 33-46. [CrossRef]

20. Lackmann, J.-W.; Schneider, S.; Edengeiser, E.; Jarzina, F.; Brinckmann, S.; Steinborn, E.; Havenith, M.; Benedikt, J.; Bandow, J.E. Photons and particles emitted from cold atmospheric-pressure plasma inactivate bacteria and biomolecules independently and synergistically. J. R. Soc. Interface 2013, 10, 20130591. [CrossRef]

21. Lackmann, J.-W.; Wende, K.; Verlackt, C.; Golda, J.; Volzke, J.; Kogelheide, F.; Held, J.; Bekeschus, S.; Bogaerts, A.; Schulz-von der Gathen, V. Chemical fingerprints of cold physical plasmas-an experimental and computational study using cysteine as tracer compound. Sci. Rep. 2018, 8, 7736. [CrossRef] [PubMed]

22. Kogelheide, F.; Kartaschew, K.; Strack, M.; Baldus, S.; Metzler-Nolte, N.; Havenith, M.; Awakowicz, P.; Stapelmann, K.; Lackmann, J.-W. FTIR spectroscopy of cysteine as a ready-to-use method for the investigation of plasma-induced chemical modifications of macromolecules. J. Phys. D Appl. Phys. 2016, 49, 084004. [CrossRef]

23. Klinkhammer, C.; Verlackt, C.; Kogelheide, F.; Bogaerts, A.; Metzler-Nolte, N.; Stapelmann, K.; Havenith, M.; Lackmann, J.-W. Elucidation of Plasma-induced Chemical Modifications on Glutathione and Glutathione Disulphide. Sci. Rep. 2017, 7, 13828. [CrossRef] [PubMed]

24. Lukes, P.; Dolezalova, E.; Sisrova, I.; Clupek, M. Aqueous-phase chemistry and bactericidal effects from an air discharge plasma in contact with water: Evidence for the formation of peroxynitrite through a pseudo-second-order post-discharge reaction of $\mathrm{H}_{2} \mathrm{O}_{2}$ and $\mathrm{HNO}_{2}$. Plasma Sources Sci. Technol. 2014, 23, 015019. [CrossRef]

25. Golda, J.; Held, J.; Redeker, B.; Konkowski, M.; Beijer, P.; Sobota, A.; Kroesen, G.; Braithwaite, N.S.J.; Reuter, S.; Turner, M. Concepts and characteristics of the 'COST Reference Microplasma Jet'. J. Phys. D Appl. Phys. 2016, 49, 084003. [CrossRef]

26. Lin, A.; Chernets, N.; Han, J.; Alicea, Y.; Dobrynin, D.; Fridman, G.; Freeman, T.A.; Fridman, A.; Miller, V. Non-Equilibrium Dielectric Barrier Discharge Treatment of Mesenchymal Stem Cells: Charges and Reactive Oxygen Species Play the Major Role in Cell Death. Plasma Process. Polym. 2015, 12, 1117-1127. [CrossRef]

27. Ellerweg, D.; Benedikt, J.; von Keudell, A.; Knake, N.; Schulz-von der Gathen, V. Characterization of the effluent of a $\mathrm{He} / \mathrm{O}_{2}$ microscale atmospheric pressure plasma jet by quantitative molecular beam mass spectrometry. New J. Phys. 2010, 12, 013021. [CrossRef]

28. Sousa, J.S.; Niemi, K.; Cox, L.; Algwari, Q.T.; Gans, T.; O'connell, D. Cold atmospheric pressure plasma jets as sources of singlet delta oxygen for biomedical applications. J. Appl. Phys. 2011, 109, 123302. [CrossRef]

29. Gorbanev, Y.; Verlackt, C.; Tinck, S.; Tuenter, E.; Foubert, K.; Cos, P.; Bogaerts, A. Combining experimental and modelling approaches to study the sources of reactive species induced in water by the COST RF plasma jet. Phys. Chem. Chem. Phys. 2018, 20, 2797-2808. [CrossRef]

30. Kelly, S.; Golda, J.; Turner, M.M.; Schulz-von der Gathen, V. Gas and heat dynamics of a micro-scaled atmospheric pressure plasma reference jet. J. Phys. D Appl. Phys. 2015, 48, 444002. [CrossRef]

31. Kruszelnicki, J.; Lietz, A.M.; Kushner, M.J. Interactions between water droplets and atmospheric pressure plasmas. Bull. Am. Phys. Soc. 2017, 62.

32. Wartewig, S. IR and Raman Spectroscopy: Fundamental Processing; John Wiley \& Sons: Hoboken, NJ, USA, 2006.

33. Lin, A.; Truong, B.; Pappas, A.; Kirifides, L.; Oubarri, A.; Chen, S.; Lin, S.; Dobrynin, D.; Fridman, G.; Fridman, A. Uniform Nanosecond Pulsed Dielectric Barrier Discharge Plasma Enhances Anti-Tumor Effects by Induction of Immunogenic Cell Death in Tumors and Stimulation of Macrophages. Plasma Process. Polym. 2015, 12, 1392-1399. [CrossRef]

34. Vermeylen, S.; De Waele, J.; Vanuytsel, S.; De Backer, J.; Van der Paal, J.; Ramakers, M.; Leyssens, K.; Marcq, E.; Van Audenaerde, J.; Smits, E.L.J. Cold atmospheric plasma treatment of melanoma and glioblastoma cancer cells. Plasma Process. Polym. 2016, 13, 1195-1205. [CrossRef]

35. Privat-Maldonado, A.; Gorbanev, Y.; Dewilde, S.; Smits, E.; Bogaerts, A. Reduction of Human Glioblastoma Spheroids Using Cold Atmospheric Plasma: The Combined Effect of Short- and Long-Lived Reactive Species. Cancers 2018, 10, 394. [CrossRef] [PubMed]

36. Turrens, J.F. Mitochondrial formation of reactive oxygen species. J. Physiol. 2003, 552, 335-344. [CrossRef] [PubMed]

37. Beckman, J.S.; Koppenol, W.H. Nitric oxide, superoxide, and peroxynitrite: The good, the bad, and ugly. Am. J. Physiol. Cell Physiol. 1996, 271, C1424-C1437. [CrossRef] 
38. Obeid, M.; Tesniere, A.; Panaretakis, T.; Tufi, R.; Joza, N.; Van Endert, P.; Ghiringhelli, F.; Apetoh, L.; Chaput, N.; Flament, C.; et al. Ecto-calreticulin in immunogenic chemotherapy. Immunol. Rev. 2007, 220, 22-34. [CrossRef]

39. Beebe, S.J.; White, J.; Blackmore, P.F.; Deng, Y.; Somers, K.; Schoenbach, K.H. Diverse effects of nanosecond pulsed electric fields on cells and tissues. DNA Cell Biol. 2003, 22, 785-796. [CrossRef]

40. Graves, D.B. Reactive species from cold atmospheric plasma: Implications for cancer therapy. Plasma Process. Polym. 2014, 11, 1120-1127. [CrossRef]

41. Baty, J.W.; Hampton, M.B.; Winterbourn, C.C. Proteomic detection of hydrogen peroxide-sensitive thiol proteins in Jurkat cells. Biochem. J. 2005, 389, 785-795. [CrossRef]

42. Girard, P.-M.; Arbabian, A.; Fleury, M.; Bauville, G.; Puech, V.; Dutreix, M.; Sousa, J.S. Synergistic effect of $\mathrm{H}_{2} \mathrm{O}_{2}$ and $\mathrm{NO}_{2}$ in cell death induced by cold atmospheric He plasma. Sci. Rep. 2016, 6, 29098. [CrossRef] [PubMed]

43. Bekeschus, S.; Wende, K.; Hefny, M.M.; Rödder, K.; Jablonowski, H.; Schmidt, A.; von Woedtke, T.; Weltmann, K.-D.; Benedikt, J. Oxygen atoms are critical in rendering THP-1 leukaemia cells susceptible to cold physical plasma-induced apoptosis. Sci. Rep. 2017, 7, 2791. [CrossRef] [PubMed]

44. Verlackt, C.; Van Boxem, W.; Bogaerts, A. Transport and accumulation of plasma generated species in aqueous solution. Phys. Chem. Chem. Phys. 2018, 20, 6845-6859. [CrossRef] [PubMed]

45. Privat-Maldonado, A.; Gorbanev, Y.; O'Connell, D.; Vann, R.; Chechik, V.; Woude, M.W. Nontarget Biomolecules Alter Macromolecular Changes Induced by Bactericidal Low-Temperature Plasma. IEEE Trans. Radiat. Plasma Med. Sci. 2018, 2, 121-128. [CrossRef] [PubMed]

46. Halliwell, B.; Gutteridge, J.M. Free Radicals in Biology and Medicine; Oxford University Press: Oxford, UK, 2015.

47. Hefny, M.M.; Pattyn, C.; Lukes, P.; Benedikt, J. Atmospheric plasma generates oxygen atoms as oxidizing species in aqueous solutions. J. Phys. D Appl. Phys. 2016, 49, 404002. [CrossRef]

48. Ellerweg, D.; von Keudell, A.; Benedikt, J. Unexpected $\mathrm{O}$ and $\mathrm{O}_{3}$ production in the effluent of $\mathrm{He} / \mathrm{O}_{2}$ microplasma jets emanating into ambient air. Plasma Sources Sci. Technol. 2012, 21, 034019. [CrossRef]

49. Mastanaiah, N.; Banerjee, P.; Johnson, J.A.; Roy, S. Examining the role of ozone in surface plasma sterilization using dielectric barrier discharge (DBD) plasma. Plasma Process. Polym. 2013, 10, 1120-1133. [CrossRef]

50. Fujii, Y.; Tomita, K.; Sano, H.; Yamasaki, A.; Hitsuda, Y.; Adcock, I.M.; Shimizu, E. Dissociation of DNA damage and mitochondrial injury caused by hydrogen peroxide in SV-40 transformed lung epithelial cells. Cancer Cell Int. 2002, 2, 16. [CrossRef]

51. Tanaka, H.; Nakamura, K.; Mizuno, M.; Ishikawa, K.; Takeda, K.; Kajiyama, H.; Utsumi, F.; Kikkawa, F.; Hori, M. Non-thermal atmospheric pressure plasma activates lactate in Ringer's solution for anti-tumor effects. Sci. Rep. 2016, 6, 36282. [CrossRef]

52. Bruno, G.; Heusler, T.; Lackmann, J.-W.; von Woedtke, T.; Weltmann, K.-D.; Wende, K. Cold physical plasma-induced oxidation of cysteine yields reactive sulfur species (RSS). Clin. Plasma Med. 2019, 14, 100083. [CrossRef]

53. Uchida, G.; Mino, Y.; Suzuki, T.; Ikeda, J.-I.; Suzuki, T.; Takenaka, K.; Setsuhara, Y. Decomposition and oxidation of methionine and tryptophan following irradiation with a nonequilibrium plasma jet and applications for killing cancer cells. Sci. Rep. 2019, 9, 6625. [CrossRef] [PubMed]

54. Sasaki, S.; Kanzaki, M.; Kaneko, T. Calcium influx through TRP channels induced by short-lived reactive species in plasma-irradiated solution. Sci. Rep. 2016, 6, 25728. [CrossRef] [PubMed]

55. Paulsen, C.E.; Carroll, K.S. Cysteine-mediated redox signaling: Chemistry, biology, and tools for discovery. Chem. Rev. 2013, 113, 4633-4679. [CrossRef] [PubMed]

56. Gupta, V.; Carroll, K.S. Sulfenic acid chemistry, detection and cellular lifetime. Biochim. Et Biophys. Acta (Bba) Gen. Subj. 2014, 1840, 847-875. [CrossRef] [PubMed]

57. Xu, H.; Wang, S.; Shaban, M.; Montazersadgh, F.; Alkayal, A.; Liu, D.; Kong, M.G.; Buckley, B.R.; Iza, F. trans-Stilbene epoxidation by $\mathrm{He}+\mathrm{O}_{2}$ atmospheric pressure plasma: Epoxidation without oxidant waste stream. Plasma Process. Polym. 2020, 17, 1900162. [CrossRef]

58. Gorbanev, Y.; Van der Paal, J.; Van Boxem, W.; Dewilde, S.; Bogaerts, A. Reaction of chloride anion with atomic oxygen in aqueous solutions: Can cold plasma help in chemistry research? Phys. Chem. Chem. Phys. 2019, 21, 4117-4121. [CrossRef]

59. Jirásek, V.; Lukeš, P. Formation of reactive chlorine species in saline solution treated by non-equilibrium atmospheric pressure $\mathrm{He} / \mathrm{O}_{2}$ plasma jet. Plasma Sources Sci. Technol. 2019, 28, 035015. [CrossRef] 
60. Sies, H. Glutathione and its role in cellular functions. Free Radic. Biol. Med. 1999, 27, 916-921. [CrossRef]

61. Franco, R.; Cidlowski, J. Apoptosis and glutathione: Beyond an antioxidant. Cell Death Differ. 2009, 16, 1303. [CrossRef] 